\title{
A Study on Scientific, Economic and Management Orientation of Coconut Growers of East Godavari District of Andhra Pradesh, India
}

\author{
Sudhamini Yedida*, A. K. Singh, Shreya Anand and Satya Prakash
}

Department of Extension Education, Dr. Rajendra Prasad Central Agricultural University, Pusa, Samastipur, Bihar, India

*Corresponding author

\begin{abstract}
A B S T R A C T
Keywords

Scientific orientation,

Economic orientation,

Management orientation East Godavari district, Coconut Growers

Article Info

Accepted:

22 June 2020

Available Online:

10 July 2020

The coconut palm which is commonly recognized as KALPAVRISHA, botanically known as "Cocusnucifera" is economically very important horticultural plantation crop in East Godavari district of Andhra Pradesh as it is crucial in shaping the social livelihood of people. The present study aims at measuring the extent of different orientations of the coconut growers of East Godavari district. This study elucidates the levels of scientific, economic and management orientation of coconut growers. The study reveals that $69 \%$ of the total selected respondents were with medium level of scientific orientation followed by $16 \%$ with high and $15 \%$ with low level of scientific orientation. It was found that $54 \%$ of the total selected respondents were categorized under medium level of economic orientation followed by $22 \%$ with low level and $19 \%$ with high level. It was also evident from the study that majority of the respondents i.e., $65 \%$ were categorized under medium level of management orientation followed by $19 \%$ of respondents who were found to have high level of management orientation and $16 \%$ of the respondents were found to possess low levels of management orientation.
\end{abstract}

\section{Introduction}

The coconut is considered as unique horticulture crop of India because of its diverse uses and products of everyday life. Therefore, coconut production, productivity and its marketing have become an attractive area of research with multidisciplinary approaches. The coconut palm which is commonly recognized as KALPAVRISHA, botanically known as "Cocusnucifera" belongs to the kingdom Plantae, sub kingdom
Tracheobionta, super division Spermatophyta, division Magnoliozphyta, class Liliopsida, sub class Arecidae, order Arecales, family Arecaceae, genus Cocos, species nucifera. Coconut is originated in Indo-Malayan Region [South East Asia]. The crop of coconut is economically very important because it provides a variety of products like Copra, Tender nuts, Coconut water, Coir, Shell based products, Fuel, Toddy, Coconut leaf for roofing and thatching purposes in rural areas. Over one crore people in the 
country are dependent on coconut for their livelihood. In this context it is stated that coconut is an important cash crop as well as crucial in shaping social livelihood of people of India and Andhra Pradesh. India ranks third in the world in terms of area of coconut after Indonesia and Philippines four Southern states i.e., Kerala, Tamil Nadu, Karnataka and Andhra Pradesh accounts for more than 90\% of India's coconut production. In this context it is stated that coconut is an important cash crop as well as crucial in shaping social livelihood of people of India and Andhra Pradesh.

This study reveals the extent of different orientations of the coconut growers. The orientations under study were Scientific orientation, Economic orientation and Management orientation. Scientific orientation refers to the respondent's orientation towards new and scientific approaches that can be employed in cultivation aspects. Economic orientation refers to the extent of orientation of respondents towards monetary values and economic returns.

Management orientation in the context of present study was expressed as the degree to which a respondent was oriented towards the scientific farm management in terms of planning, production, and marketing in coconut cultivation. It comprises of Planning orientation, Production orientation and Marketing orientation. By knowing the extent of these levels we can get a brief idea about the coconut growers' orientation towards different aspects.

\section{Materials and Methods}

\section{Research Design}

Ex-post facto research design was adopted for the study. This design was considered appropriate for the study as the variables of the study had already occurred and measurement of the selected variables was taken up only after the occurrence of the event.

\section{Sampling Procedure}

The study was conducted in Andhra Pradesh. The state occupies fourth place in area and production of coconut in the country and supersedes the top three states in productivity. So, Andhra Pradesh state was purposively selected for the study. In Andhra Pradesh East Godavari district occupies first place in area and production of coconut. So, it was purposively selected for the study. In the district among 65 mandals two mandals namely Ainivilli and I.Polavarammandal based on the similar criteria as adopted in the selection of the district were selected. Further four villages two from each mandal were identified based on the same assumptions. They were Chintanalanka, Madupalle from Ainivillimandal and Pasuvullanka and Yedurulanka from I. Polavarammandal.

\section{Selection of Respondents}

The coconut growers in the selected villages were considered as the sample. A total of 100 respondents were randomly selected from the study area i.e., 25 respondents from each village for the study.

\section{Data Collection}

The data was collected using well-structured interview schedule in personal interview mode. The questions/statements of the schedule were asked from the respondent in the local language i.e. in Telugu. Each of the respondent was personally contacted and after making rapport they had been interviewed with the help of structured schedule. 


\section{Statistical Tools Used}

The collected data was analyzed using frequency analysis, percentage analysis, Arithmetic Mean and Standard Deviation and interpreted.

\section{Results and Discussion}

Scientific orientation refers to the respondent's orientation towards new and scientific approaches that can be employed in cultivation aspects. It was measured using a suitable scale consisting of six statements. The statement which was in agreement with maximum number of respondents was "Improved methods of coconut cultivation give better results to a farmer than old methods" followed by the statement "Even a farmer with lot of experience should use improved methods of coconut cultivation" and majority of the respondents expressed their disagreement towards the statement "The way a farmer's forefather have done in coconut cultivation is still the best way to follow today." The maximum score obtained was 29 and minimum score recorded was 14 . Based on the scores obtained by the respondents they were categorized into three categories viz., low, medium, high categories in the present study according to their scientific orientation. The table 1 depicts the distribution of respondents according to their scientific orientation. By careful observation of the table 1, it was evident that $69 \%$ of the total selected respondents were with medium level of scientific orientation followed by $16 \%$ were found to have high levels of scientific orientation and only $15 \%$ of the respondents were found to have low level of scientific orientation. In Chintana Lanka village it was found that $64 \%$ of the total selected respondents belonged to medium category of scientific orientation followed by $24 \%$ of respondents to low category and $12 \%$ to high category of scientific orientation while in Madupalle village a lion's share i.e., $80 \%$ of the total respondents belonged to medium category of scientific orientation and $12 \%$ to high category and only $8 \%$ of respondents possessed low level of scientific orientation. In Yedurulanka village majority of the selected respondents i.e., $68 \%$ were categorized under medium category of scientific orientation followed by equal percentage of respondents i.e., $16 \%$ each under low category and high category of scientific orientation. Similarly, majority i.e., $64 \%$ of the selected respondents in Pasuvullanka village also belonged to medium level of scientific orientation followed by $24 \%$ of the population to high level of scientific orientation and only $12 \%$ to low level of scientific orientation.

Economic orientation refers to the extent of orientation of respondents towards monetary values and economic returns. It was measured with the help of a scale consisting of six statements. Among all the statements, the statement which was agreed by maximum number of respondents was "A farmer should work towards larger yields and economic gains." In the present study maximum score obtained by an individual respondent was 28 and minimum score recorded was 14 and based on the scores of the individual respondents they were categorized into three categories viz., low, medium and high according to their economic orientation. The table 2 shows the distribution of respondents according to their economic orientation and it was revealed from the table that $54 \%$ of the total selected respondents were categorized under medium level of economic orientation followed by $22 \%$ with low level and $19 \%$ of the respondents were found with high level of economic motivation. In Chintana Lanka village $48 \%$ of the selected respondents were found to possess medium level of economic orientation followed by $40 \%$ of the respondents belonged to low level and $12 \%$ of 
the selected respondents were found to have high level of economic orientation. The Madupalle village was characterized by $48 \%$ of respondents under medium level of economic orientation followed by $32 \%$ of the respondents under high level and 20\% under low level of economic orientation. A lion's share of $76 \%$ of the total selected respondents in Yedurulanka village possessed medium level of economic orientation followed by $16 \%$ of the respondents were found to possess low economic orientation and only $8 \%$ of the respondents were with higher levels of economic orientation. Likewise, majority of the respondents i.e., $64 \%$ of respondents in Pasuvullanka village were found under medium level of economic orientation followed by $24 \%$ of the respondents with high level of economic orientation and only $12 \%$ of the respondents were belong to low level of economic orientation.

Management orientation in the context of present study was expressed as the degree to which a respondent was oriented towards the scientific farm management in terms of planning, production, and marketing in coconut cultivation. Statements pertaining to planning, production and marketing aspects were asked and the extent of agreement towards the statements by the respondents was reported to determine the management orientation of the respondents. The maximum score obtained by the respondents was 52 and minimum was 31 . The respondents were more oriented towards the production aspects followed by marketing and planning aspects. The statement that gained maximum agreement in planning orientation was "It is possible to increase the yield through farm production plan" and in production and marketing orientation were "For timely plant protection measures one should use suitable chemicals" and "One should grow those varieties which have more market demand" respectively. The statement which was disagreed by maximum number of respondents in planning orientation was "It is not necessary to make prior decision about the practices to be followed" and in production orientation was "One should use as much fertilizer as he likes" and in marketing orientation was "Market news is not so much useful to a farmer." The scores obtained by the respondents in planning, production and marketing orientation were summed up to get their overall management orientation and categorized into three categories viz., low, medium and high according to their management orientation and details of results were presented here through table 3 .

The table 3 depicts the distribution of respondents according to their mode of management orientation. A glance at the table reveals that majority of the respondents i.e., $65 \%$ were categorized under medium level of management orientation followed by $19 \%$ of respondents who were found to have high level of management orientation and $16 \%$ of the respondents were found to possess low levels of management orientation. In Chintana Lanka village there were $64 \%$ of the total selected respondents who belonged to the groups of medium level of management orientation followed by $24 \%$ of the respondents having low level of management orientation and $12 \%$ of the respondents were found to possess high level of management orientation.

The majority i.e., $64 \%$ of respondents of Madupalle village were possessing medium level of management orientation followed by $20 \%$ were with high level and 16\% were categorized under low category of management orientation. A lion's share of $76 \%$ of the respondents were found under medium category in Yedurlanka village followed by $16 \%$ of the total respondents under high and $8 \%$ were under low category of management orientation. The maximum 
percentage of respondents i.e., $56 \%$ were categorized under medium category in Pasuvullanka village followed by $28 \%$ under high category and $16 \%$ under low category of management orientation.

Table.1 Distribution of respondents according to their Scientific Orientation

\begin{tabular}{|c|c|c|c|c|c|}
\hline \multirow[b]{2}{*}{ Category } & \multicolumn{2}{|c|}{ Ainivillimandal } & \multicolumn{2}{|c|}{ I. Polavarammandal } & \multirow[b]{2}{*}{ Total } \\
\hline & $\begin{array}{c}\text { Chintana Lanka } \\
\text { f } \\
(\%)\end{array}$ & $\begin{array}{c}\text { Madupalle } \\
\text { f } \\
(\%)\end{array}$ & $\begin{array}{c}\text { Yedurulanka } \\
\text { f } \\
(\%)\end{array}$ & $\begin{array}{c}\text { Pasuvullanka } \\
\text { f } \\
(\%)\end{array}$ & \\
\hline \multirow[t]{2}{*}{ Low } & 6 & 2 & 4 & 3 & \multirow[t]{2}{*}{15} \\
\hline & $(24 \%)$ & $(8 \%)$ & $(16 \%)$ & $(12 \%)$ & \\
\hline \multirow[t]{2}{*}{ Medium } & 16 & 20 & 17 & 16 & \multirow[t]{2}{*}{69} \\
\hline & $(64 \%)$ & $(80 \%)$ & $(68 \%)$ & $(64 \%)$ & \\
\hline \multirow{2}{*}{ High } & 3 & 3 & 4 & 6 & \multirow[t]{2}{*}{16} \\
\hline & $(12 \%)$ & $(12 \%)$ & $(16 \%)$ & $(24 \%)$ & \\
\hline
\end{tabular}

Mean: 22.58; S.D: 2.96

Table.2 Distribution of respondents according to their Economic Orientation

\begin{tabular}{|c|c|c|c|c|c|}
\hline \multirow{2}{*}{ Category } & \multicolumn{2}{|c|}{ Ainivillimandal } & \multicolumn{2}{|c|}{ I. Polavarammandal } & \multirow{2}{*}{ Total } \\
\cline { 2 - 5 } & $\begin{array}{c}\text { Chintana Lanka } \\
\mathbf{f}\end{array}$ & $\begin{array}{c}\text { Madupalle } \\
\mathbf{f}\end{array}$ & $\begin{array}{c}\text { Yedurulanka } \\
\mathbf{f}\end{array}$ & $\begin{array}{c}\text { Pasuvullanka } \\
\mathbf{f}\end{array}$ & \\
\hline Low & 10 & $(\boldsymbol{\%})$ & $(\mathbf{\%})$ & $(\mathbf{\%})$ & \\
\hline \multirow{2}{*}{ Medium } & $(40 \%)$ & $(20 \%)$ & $(16 \%)$ & $(12 \%)$ & $\mathbf{2 2}$ \\
\hline \multirow{2}{*}{ High } & 12 & 12 & 19 & 16 & $\mathbf{5 9}$ \\
& $(48 \%)$ & $(48 \%)$ & $(76 \%)$ & $(64 \%)$ & \multirow{2}{*}{$\mathbf{1 9}$} \\
\hline & 3 & 8 & 2 & 6 & \\
\hline
\end{tabular}

Mean: 22.85; S.D: 2.76

Table.3 Distribution of respondents according to their Management Orientation

\begin{tabular}{|c|c|c|c|c|c|}
\hline \multirow[b]{2}{*}{ Category } & \multicolumn{2}{|c|}{ Ainivillimandal } & \multicolumn{2}{|c|}{ I. Polavarammandal } & \multirow[b]{2}{*}{ Total } \\
\hline & $\begin{array}{c}\text { ChintanaLanka } \\
\text { f } \\
(\%)\end{array}$ & $\begin{array}{c}\text { Madupalle } \\
\text { f } \\
(\%)\end{array}$ & $\begin{array}{c}\text { Yedurulanka } \\
\text { f } \\
(\%)\end{array}$ & $\begin{array}{c}\text { Pasuvullanka } \\
\mathbf{f} \\
(\%)\end{array}$ & \\
\hline \multirow[t]{2}{*}{ Low } & 6 & 4 & 2 & 4 & \multirow[t]{2}{*}{16} \\
\hline & $(24 \%)$ & $(16 \%)$ & $(8 \%)$ & $(16 \%)$ & \\
\hline \multirow[t]{2}{*}{ Medium } & 16 & 16 & 19 & 14 & \multirow[t]{2}{*}{65} \\
\hline & $(64 \%)$ & $(64 \%)$ & $(76 \%)$ & $(56 \%)$ & \\
\hline \multirow[t]{2}{*}{ High } & 3 & 5 & 4 & 7 & \multirow[t]{2}{*}{19} \\
\hline & $(12 \%)$ & $(20 \%)$ & $(16 \%)$ & $(28 \%)$ & \\
\hline
\end{tabular}




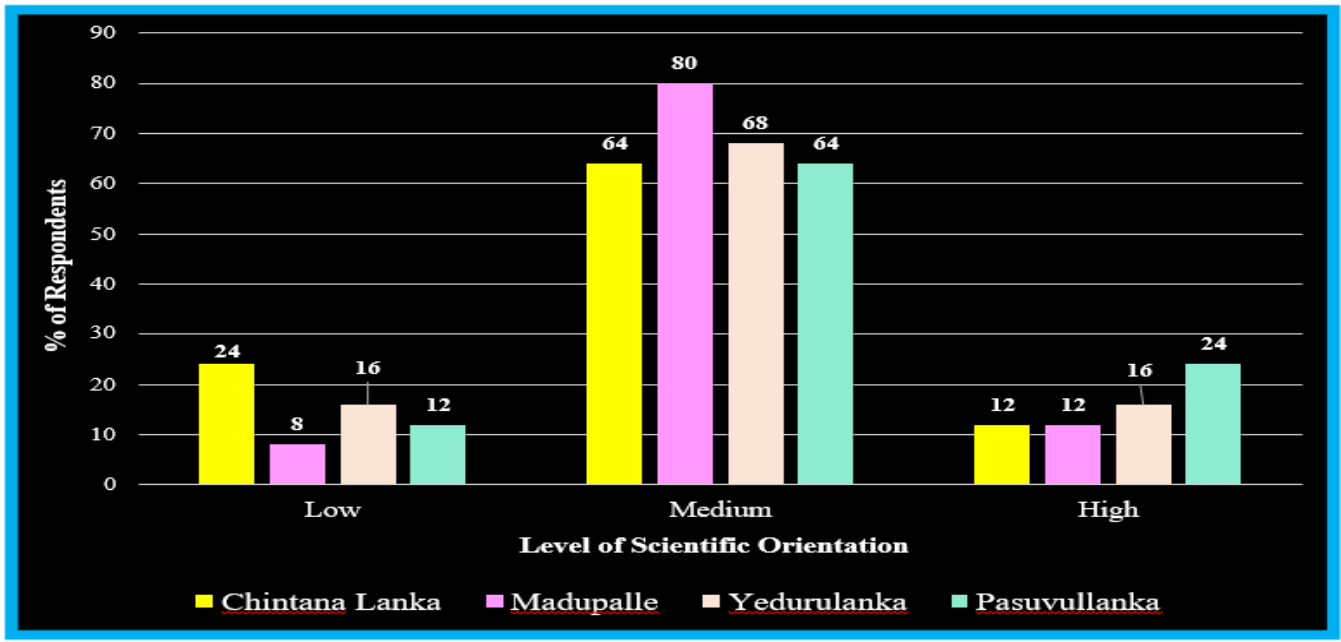

Figure 1: Distribution of respondents according to their Scientific Orientation

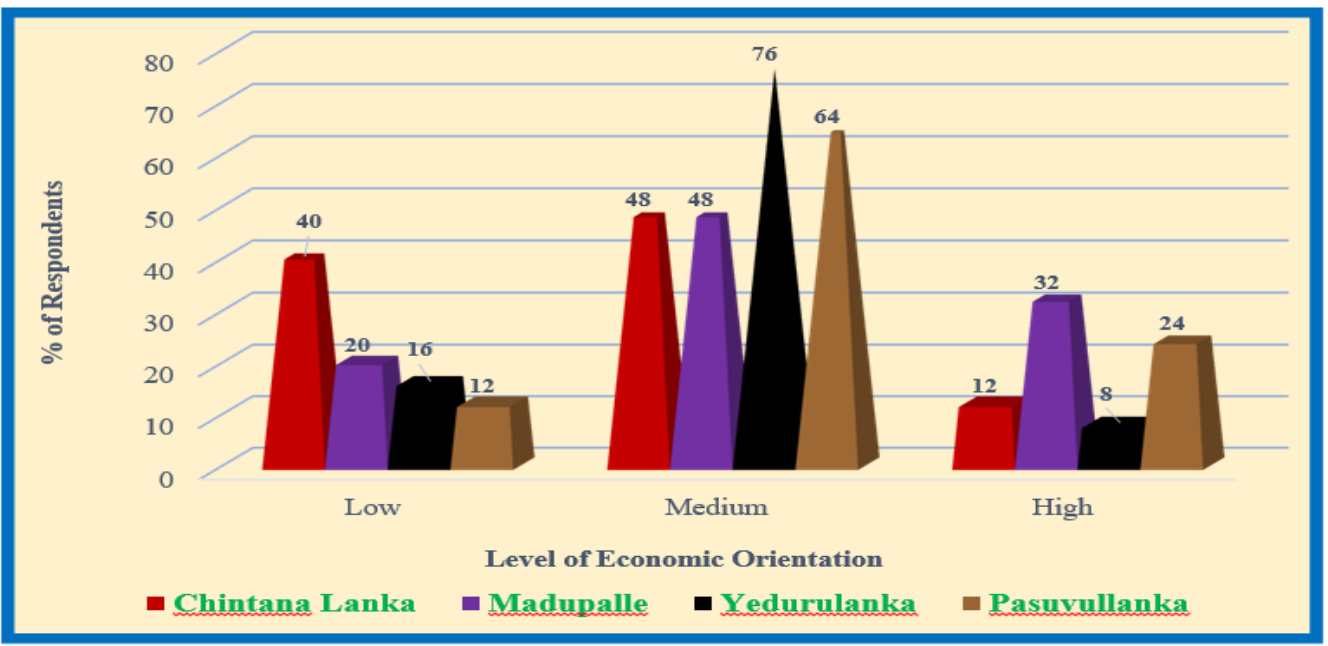

Figure 2: Distribution of respondents according to their Economic Orientation

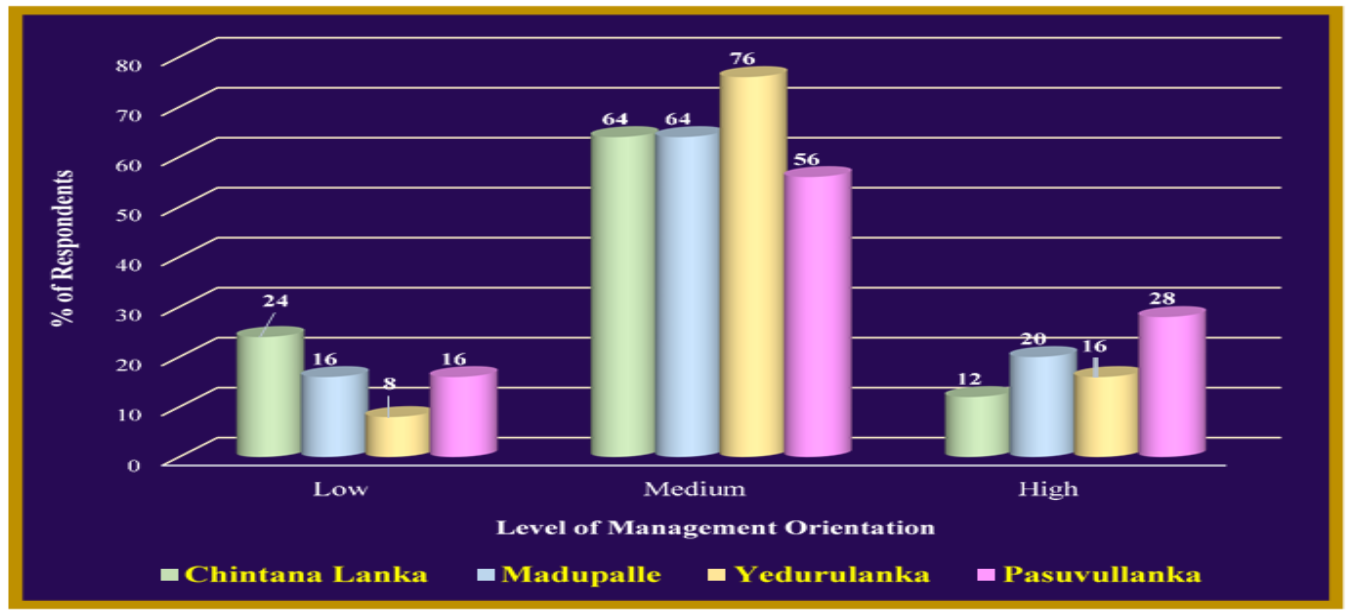

Figure 3: Distribution of respondents according to their Management Orientation 


\section{Scientific Orientation}

Majority of the respondents possess medium level of scientific orientation. From the depiction of Figure 1, it could be inferred that majority of the respondents had medium level of scientific orientation. This might be due to the reason that only medium number of respondents were oriented towards the use of scientific practices which involve high cost of cultivation and promise uncertain returns. In addition, the extension personnel were concentrating more on progressive/ big farmers rather than medium and small farmers. Further, majority of the farmers were medium to old aged with stereotypic mentality and less enthusiastic to know the things scientifically.

\section{Economic Orientation}

It could be comprehended from the Figure 2 that majority of the respondents had medium economic orientation. The plausible reason for this trend might be that respondents were still considering agriculture as a subsistence occupation and not as an agripreneur. Further, the uncertainty level of the farmers was found to be increasing day-by-day because of many factors such as prevalence of change in climatic condition, fluctuating market prices, absence of timely market intelligence, seasonality of price, shortage of skilled / unskilled labourers and increase in the cost of agricultural inputs etc., made them skeptical about profit from agriculture. Therefore, a concerted efforts are needed for improving economic orientation of coconut farmers in terms of choice of technologies, situation based specific combinations of resource utilization, planning for maximum utilization of natural, personal, economic and knowledge resources for realizing profit maximization and preserving farm resources. For this purpose farmers can be taken for exposure visits and study tours to educate them about better use of inputs and profit maximization so that they get inspired in harvesting more yield and consequently money from their farm holding

\section{Management Orientation}

From the perusal of results from Figure 3, it could be seen that majority of respondents have medium management orientation. The medium levels of scientific orientation, extension contact and communication behaviour especially mass media exposure might be the reasons for majority of the farmers falling under the category of medium level of management orientation in spite of having better level of educational background. The management orientation of any farmer indicates factors like planning production and marketing activities, acquiring knowledge and technical aspects, skill sharpening, resource appraisal, gap analysis in production/ marketing and value addition aspects of coconut farming. The management orientation determines the efficiency and capacity of farmers in the decision making for their farming activities. Hence improved management skills were required for the future glorious performance of coconut as an economic and social crop.

\section{References}

Kadiri, Mohan and Ramesh, Kumar Reddy, P. (2012). Profile characteristics of farmers under tank irrigation commands. Karnataka Journal of Agricultural Sciences. 25(3): 359-362.

MukeshYadav, Kinjulck, C. Singh, Chouhan, A.S. and Singh, C.J. (2013). "TechnoEconomic Changes among the Farmers in Relation to Watershed Development Programme. Indian Research Journal of Extension Education 13(1):31-34.

Ramakrishna Rao, L., Shivamurthy, M and Lakshminarayan, M.T. (2008). Adoption 
of sustainable coconut and banana intercropping practices - An analysis. Mysore Journal of Agricultural Sciences 42(1):67-74.

Saikia S, Barman, U. and Pathak, K. (2014). Determinants of Variables Associated With Adoption Behaviour of Farmers Towards Recommended Production Technologies Of Winter Rice in Assam. Society for Recent Development in Agriculture. Progressive Agriculture. 14(2): 214-218.

Shivalingaiah and Srikanthamurthy. (2001). "Adoption of improved coconut cultivation practices and constraints faced by coconut growers". Journal of
Extension Education, 12(1): 2991-2994. Singh, R.K. and Sujata, Ghose. (2003). Coconut development in Andaman and Nicobar Islands. Indian Coconut Journal, 33(8): 1-6.

Thampan, P.K. (1998). "The strategy of coconut development in root wilt affected coconut tracts in Kerala". Indian Coconut Journal, 23(9): 1-5.

Thippeswamy, R., Syed Sadaqath, Manjunath, L. and Hirevenkanagoudar, I.V. (2008). A study on knowledge and extent of adoption of plant protection measures in coconut crop. Karnataka Journal Agricultural Sciences., 21(3): 412-415.

\section{How to cite this article:}

Sudhamini Yedida, A. K. Singh, Shreya Anand and Satya Prakash. 2020. A Study on Scientific, Economic and Management Orientation of Coconut Growers of East Godavari District of Andhra pradesh. Int.J.Curr.Microbiol.App.Sci. 9(07): 3503-3510. doi: https://doi.org/10.20546/ijcmas.2020.907.410 